cated to small science, which may not be cut without his approval.

\section{National Aeronautics and Space Administration}

The theme of this year's space budget is 'steady as she goes'. Total NASA spending planned for fiscal year 1993 stands at $\$ 14,993$ million, an increase of just 4.5 per cent over last year. Room has been made to increase support for Space Station Freedom, from $\$ 2,030$ million to $\$ 2,250$ million, and for the Earth Observing System, which will rise by over one-third to $\$ 308$ million. To pay for these outlays, a few wholesale cuts were made, notably the cancellation of the $\$ 470$ million Advanced Solid Rocket Motor programme, a deliberate challenge to its principal congressional supporter, Jamie Whitten (Democrat, Mississippi), chairman of the House appropriations committee. The Comet Rendezvous and Asteroid Fly-by (CRAF) mission and a shuttleborne relativity experiment are also eliminated.

The most difficult decision, said NASA administrator Admiral Richard Truly, was to cut CRAF. Its twin, Cassini (which is to visit Saturn), is retained, but with funding for Magellan's Venus-mapping mission scheduled to end, and with Galileo still Jupiter-bound but almost incommunicado because of the failure of its high-speed data transmitter, the US solar system exploration programme seems to be headed for a lean period. Only the US-European solar probe Ulysses is in space, on target, and working perfectly.

\section{Biotechnology}

In the face of stiff competition from other countries, principally Japan, whose government is targeting the biotechnology industry in much the same way it targeted the semiconductor industry, the Administration plans to give US biotechnology its own multi-agency initiative. By cobbling together all the existing federal research that has anything to do with biotechnology, and finding a small amount of new money, the budget proposes a $\$ 4,030 \mathrm{mil}$ lion programme spread out over 12 agencies. This is, the Administration says, an increase of 7 per cent from 1992 funding levels. Although industrial investment in biotechnology shows no sign of letting up, the Administration believes that there is untapped potential in areas relating to manufacturing, bioprocessing, energy and the environment.

William Small, executive director of the Association of Biotechnology Companies, says the Bush initiative is a "positive first step, but only that", and said that fewer regulations and faster patent and product approvals are needed to bring products to the marketplace.

Christopher Anderson, David Lindley \& Diane Gershon

\title{
At frontier's end, the "P" word
}

\section{Washington}

VANNEVAR Bush, the postwar US science advisor, called science "the endless frontier", and recommended, in short, that scientists be given money freely in the expectation that from this disinterested largesse technological and social benefits would necessarily flow. But in recent years, increasing austerity has made the future seem less than infinite. As Congress prepares to set the research budget for another year of grim economics, funding in many areas is expected to be flat or worse, and politicians are looking for projects to cut in order that the rest might be saved. But deciding which ones to axe and which to spare is turning out to be the usual muddle, due in part to the science community's traditional unwillingness to choose favourites.

For a ranking based on quality of science, there seems to be no one to ask but the scientists themselves. But they, for the most part, are not saying. The "P" word, priorities, is anathema; for most researchers, a priority ranking of research projects is perceived, usually rightly, as an execution list in reverse order. In a report* released last month by the National Academy of Sciences (NAS) on long-term space research planning, the NAS space studies board listed a half-dozen scary arguments why scientist avoid priorities like the plague. But for each argument it provided a counter-argument. The negative reason for scientists to set priorities is that if they do not, someone else will; the positive reason is that if scientists can indeed choose and then (the hard part) keep their consensus together, they may find themselves with real political power.

Of course, advice is easy to give, and the NAS report does no priority-setting of its own. The first phase of the study, now completed, aimed simply to make the case that setting priorities is a good idea. The second phase, now begun, is to "attempt to develop a credible methodology that the...community could use to recommend priorities." Clearly this priority-setting business is no picnic.

A revealing example of the perils of setting priorities appeared last month in a Washington Post series on Vice President Dan Quayle, head of the National Space Council, which was resurrected in 1989 to coordinate the Administration's space policy. The panel, which was composed of prominent scientists and aerospace executives, was preparing the "Augustine report" to recommend NASA's agenda for the next decade (see Nature 348, 569; 1990). According to the account of a key meeting, panel members were clear on where NASA's priorities should lie: basic science first, then technology, then environmental studies, then a new launch ve- hicle, and finally the space station and a mission to Mars.

Fortunately for the two lowest-ranked programmes, Richard Darman, director of the White House Office of Management and Budget, was in attendance at the meeting. Nothing if not familiar with the ways of Washington, Darman warned the panel that listing something last was an invitation to kill it. In fact, he said, ranking things at all was only going to give Congress ammunition to undermine Bush's space policy.

The final report listed science as most importance, but lumped together all the other space efforts into a single "balanced" programme, without ranked priorities.

Even when scientists do fight the gag reflex and actually set priorities, the may not get what they want. Surveys by the astronomy community, conducted every ten years since 1970 , have provided a solid political base for many of the country's large astronomical facilities. But the latest NAS astronomy survey, chaired by John Bahcall and released in March last year, listed as its top priority the $\$ 1,300$ million Space Infrared Telescope Facility (SIRTF), only to find that the NASA budget released last week mentions SIRTF nowhere. The project is simply too expensive to contemplate for now.

Asked last week what conclusion researchers should draw from seeing the astronomers' first pick cut altogether, White House science advisor Allen Bromley said the lesson is that scientists are "only one voice among many." They can either set priorities and be an articulate voice, he cautioned, or argue for more of everything and get lost in the noise.

At a meeting with the press last week, Representative George Brown (Democrat, California), chairman of the House Science, Space and Technology Committee, warned that the penalty to be paid for trying to stay above the political fray by not choosing priorities is that political earmarking will reign supreme. "I cannot overemphasize the importance of making scientific merit the first and chief criteria used to judge a research area...free of any other distillation or filtering," he said. "Without this primary ranking, policy makers lose their only opportunity for an unadulterated, peer-reviewed judgment of the science." The administration estimates that earmarking robs research of 15 per cent of its funding. Whether clearer priorities from the scientific community would have dissuaded Congress from indulging in its pork habit is not clear. But as Brown pointed out, it cannot hurt.

Christopher Anderson \& David Lindley

* Setting Priorities for Space Research:Opportunities and Imperatives. Space Studies Board, National Research Council. 1991 